\title{
Sustainable Innovation in Membrane Technologies for Produced Water Treatment: Challenges and Limitations
}

\author{
Haneen Abdelrazeq, Majeda Khraisheh*(D), Hafsa Mohammed Ashraf, Parisa Ebrahimi and Ansaruddin Kunju \\ Department of Chemical Engineering, College of Engineering, Qatar University, Doha 2713, Qatar; \\ ha082881@student.qu.edu.qa (H.A.); ha1402235@student.qu.edu.qa (H.M.A.); \\ pe1904870@student.qu.edu.qa (P.E.); aa1203886@student.qu.edu.qa (A.K.) \\ * Correspondence: m.khraisheh@qu.edu.qa; Tel.: +974-4403-4993
}

check for updates

Citation: Abdelrazeq, H.; Khraisheh, M.; Ashraf, H.M.; Ebrahimi, P.; Kunju,

A. Sustainable Innovation in

Membrane Technologies for

Produced Water Treatment:

Challenges and Limitations.

Sustainability 2021, 13, 6759.

https://doi.org/10.3390/su13126759

Academic Editors:

Ramon Sala-Garrido and

María Molinos-Senante

Received: 4 May 2021

Accepted: 8 June 2021

Published: 15 June 2021

Publisher's Note: MDPI stays neutral with regard to jurisdictional claims in published maps and institutional affiliations.

Copyright: (c) 2021 by the authors. Licensee MDPI, Basel, Switzerland This article is an open access article distributed under the terms and conditions of the Creative Commons Attribution (CC BY) license (https:// creativecommons.org/licenses/by/ $4.0 /)$.

\begin{abstract}
Discharged water from the oil and gas fields is a common type of wastewater called produced water (PW). It consists of different combinations of salinities, oils, and mineral deposits. Growing industrial demand, accelerated urbanization, and rapid population growth are putting enormous strain on the world's water supply. Based on sustainable freshwater supplies, North Africa, the Middle East, and South Asia confront the ultimate water shortages threat. Proper implementation of innovative membrane technologies in wastewater treatment is considered a solution towards tackling water insecurity and sustainability. Different types of innovative membrane technologies used for produced water treatment were considered in this work. A framework of innovative membrane technology was studied for industrial wastewater with direct contribution to the environmental and economical sustainability factors, taking into consideration grand challenges and limitations in energy costs and environmental constraints. Treated produced water can be utilized in irrigation providing many benefits only if the desalination sector is mature and fully developed.
\end{abstract}

Keywords: oil and gas production; produced water; wastewater treatment; innovative membrane technology; sustainable processes

\section{Introduction}

\subsection{Produced Water from the Oil and Gas Industry}

Because of the growing requirement for petroleum and byproducts, as well as the demand for further oil-gas extraction, industrial discharged water from the oil-fields alone is the largest waste production encountered nowadays [1,2]. As listed in Table 1, the physical characteristics of such wastewaster correspond to the different geographical locations of the industrial plant [3]. Significant quantities of this produced water is confined within the oil reservoirs and is high in salinity [4]. Flowback and surface water from ponds, lakes, or rivers, and even smaller sources of fresh or brackish water in ponds or rivers, can sometimes be part of produced water (PW), and therefore it may be a problem [5].

It is worth noting that the volume of water produced from the gas industrial sectors is much less than that generated from the oil sector. This small amount of discharged water contains the highest acidity [6]. Additionally, because nearly one-third of the chemicals used to treat the gas end up in industrial wastewater, the gas sector becomes the immediate source of highest PW contaminants [7,8]. This results in scaling and corrosion of industrial equipment that negatively affect the water productivity [9]. Therefore, proper treatment most be executed to filter and disinfect the discharged industrial water to make it reliable for clearance to water surface and also re-use in irrigation and agriculture $[10,11]$. The storage, shipping, processing, and disposal of water in various stages in oil and gas manufacture is critical for industry [12]. It is important to note that quantifying the exact environmental concentrations present in produced water is a complicated procedure. Not to mention the impractical effect of such discharges on both the population and the community [13-15]. Discharged wastewater from shale oil and gas industries has been suggested for use in 
agricultural irrigation to help alleviate countries' water shortages $[16,17]$. Consequently, relevant global quality requirements should follow the chemical composition of re-used wastewater $[18,19]$.

Table 1. Global parameters of produced water from oil-field industries [8].

\begin{tabular}{|c|c|c|c|c|c|c|}
\hline Density & $\mathrm{pH}$ & TOC * & TSS * & COD * & Total Oils & Volatiles \\
\hline$\left[\mathrm{kg} / \mathrm{m}^{3}\right]$ & & {$[\mathrm{mg} / \mathrm{L}]$} & {$[\mathrm{mg} / \mathrm{L}]$} & {$[\mathrm{mg} / \mathrm{L}]$} & {$[\mathrm{mg} / \mathrm{L}]$} & {$[\mathrm{mg} / \mathrm{L}]$} \\
\hline $1014-1140$ & $4.3-10$ & $0-1500$ & $1.2-1000$ & 1220 & $2-565$ & $0.35-0.39$ \\
\hline $\begin{array}{l}\text { Chloride } \\
\text { [mg/L] }\end{array}$ & $\begin{array}{l}\text { Bicarbonate } \\
{[\mathrm{mg} / \mathrm{L}]}\end{array}$ & $\begin{array}{l}\text { Sulfate } \\
{[\mathrm{mg} / \mathrm{L}]}\end{array}$ & $\begin{array}{l}\text { Sulphide } \\
{[\mathrm{mg} / \mathrm{L}]}\end{array}$ & $\begin{array}{c}\text { Ammoniacal nitrogen } \\
{[\mathrm{mg} / \mathrm{L}]}\end{array}$ & $\begin{array}{l}\text { Higher Acids } \\
{[\mathrm{mg} / \mathrm{L}]}\end{array}$ & $\begin{array}{l}\text { Phenols } \\
{[\mathrm{mg} / \mathrm{L}]}\end{array}$ \\
\hline $80-200,000$ & 77-3990 & $<2-1650$ & 10 & $10-300$ & $<1-63$ & $0.009-23$ \\
\hline
\end{tabular}

* TOC: Total organic carbon, TSS: Total suspended solids, COD: Chemical oxygen demand.

As a result, effective water treatment and reuse techniques are required for long-term life on Earth and to compensate for future water scarcity [20]. Various methods consisting of physical, chemical, and biological treatment techniques were implemented for separating oil from PW over the years [1,21-26].

\subsection{Produced Water Treatment Methods}

Desalination is the fundamental origin of consumable water in the nations of the Gulf, for example Saudi Arabia, Qatar, Kuwait, Oman, and the United Arab Emirates. In these nations, desalination represents 40 percent of the water utilized for civil and industrial aspects. Desalination of produced water in the Gulf's petrochemical industry is a continuing challenge to major research groups in the field. With a focus on produced water from desalination plants, it has become crucial to define and follow specific protocol in wastewater purification technologies. Only $0.03 \%$ of the total $70 \%$ of earth's water is consumable by humans. The demand of wastewater treatment and desalination is expected to expand as per the World Health Organization to protect up to 4 billion of the world's population from running out of clean water access $[27,28]$. Desalinated water provides most of the water used in commercial and agriculture processes. Qatar's wastewater from oil-field extractions is expected to be around 490 million $\mathrm{m}^{3}$, which is about half the yearly desalination plants' demand for fresh water in the whole GCC region. This fact presents an excellent opportunity to rethink traditional wastewater management methods and implement novel techniques, such as the use of treated process water and produced water for industrial and agricultural purposes. Treated produced water may be used for nonhuman purposes such as agricultural drainage, landscaping, building, road construction, and salinity flashing $[29,30]$. From this point rises the importance of employing membranebased separation systems in water desalination processes. Other than their simplicity of use and reasonable design costs, using membrane technologies have many benefits for produced water treatment, such as [31]:

- Minimal environmental impact, reduced energy costs, and highly automated installations.

- Widespread in oil exploration onshore and offshore.

- There is no requirement for chemical additives.

- During such processes, the membrane can be used to recycle the waste streams.

In membrane technologies, the crossflow operation mode is preferred in purifying high concentrations of saline solutions. This is because the flow of the feed is perpendicular to the flow of the permeate. This helps in reducing the amount of accumulated species on the surface of the membrane during the desalination process [32]. Similar work was done on produced water from shale oil and gas, with an emphasis on permeate flux and membrane fouling [33-36]. A list of five wastewater treatment technologies is mentioned in Table 2 with emphasis on the main benefits and limitations for each technology. 
Table 2. Advantages and drawbacks of PW treatment technologies.

\begin{tabular}{|c|c|c|c|c|c|}
\hline & \multicolumn{5}{|c|}{ Produced Water Treatment Methods } \\
\hline & Microfiltration & Ultrafiltration & Reverse Osmosis & Adsorption & Ion-Exchange \\
\hline Advantages & $\begin{array}{l}\text { High recovery of } \\
\text { fresh water }\end{array}$ & $\begin{array}{l}\text { High recovery of } \\
\text { fresh water }\end{array}$ & $\begin{array}{l}\text {-Compact module } \\
\text { - Removes dossilved } \\
\text { contaminants }\end{array}$ & $\begin{array}{l}\text { Cheap } \\
\text { Efficient } \\
\text { Compact }\end{array}$ & $\begin{array}{l}\text { Low energy required } \\
\text { Continuous } \\
\text { treatment possible }\end{array}$ \\
\hline Drawbacks & $\begin{array}{l}\text { High energy } \\
\text { required } \\
\text { Low effeciency }\end{array}$ & $\begin{array}{l}\text { High energy } \\
\text { required } \\
\text { High membrane } \\
\text { fouling }\end{array}$ & $\begin{array}{l}\text { Requires high } \\
\text { pressure } \\
\text { Small traces of } \\
\text { grease may cause } \\
\text { memb/oil causes } \\
\text { membrane fouling }\end{array}$ & $\begin{array}{l}\text { Low effeciency at } \\
\text { high feed } \\
\text { concentrations } \\
\text { High retention time }\end{array}$ & $\begin{array}{l}\text { - Requires } \\
\text { pre-treatment } \\
\text { - Requires } \\
\text { post-treatment }\end{array}$ \\
\hline
\end{tabular}

In general, approximately $9 \%$ of the papers examined employed a hybrid system for PW treatment. A number of factors immediately contributing to figuring out the exact wastewater treatment technology which needed to be applied are listed in Figure 1.

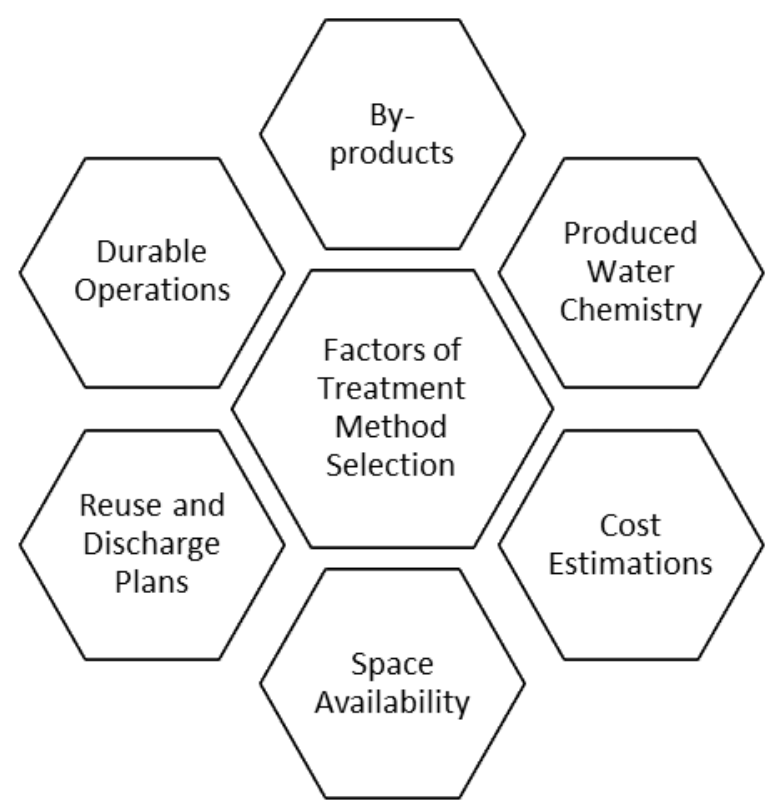

Figure 1. Aspects influencing the selection of produced water treatment techniques.

Recent work using fabricated polystyrene membranes along with a novel, activated carbon-doped, electrospun, polystyrene membrane was done by Abdelrazeq et al. [37] and Esteves et al. [38] to tackle produced water treatment using a bench-scale direct-contact membrane distillation (DCMD) bench-scale unit. Results have shown that membranes including activated carbon-doped layers showed a $20 \times$ greater specific surface area as compared to undoped membranes. However, all membranes retained their desalination capabilities despite the addition of the activated carbon. Alkhouzaam et al. [39] presented another interesting study where polydopamine functionalized graphene oxide nanoparticles (GO-PDA NPs) were prepared to investigate their structural properties in membrane separation processes. The hydrophilicity was significantly improved despite the low concentrations of GO-PDA layer (1 wt.\%) on the PS substrate. Hence, GO-PDA proved to have the potential as nanofiller due to the higher hydrophilicity and dispersibility.

Besides membranes, other treatment methods consist of $34 \%$ of the total published papers in the area of oil and gas wastewater treatment. For example, several studies examined biological treatments which are considered promising techniques for eliminating PW residuals. The effect of biodegradation of certain organic compounds existing in fluids 
during hydraulic fracturing was evaluated by Akyon et al. [40]. Another group analyzed an algal process with a highest result of $100 \%$ of the total dissolved solids eliminated from the water flux [41]. Additional approaches have also been evaluated. For instance, acid active shrimp shell as well as montmorillonite have successfully been used for the removal of heavy metal species (at efficiency of 65-93 percent) and crude oil (87 percent) from oilfield PW [42].

\subsection{Research Prospective}

Almost $19 \%$ of the papers focused on various treatment methods. While several scholars have investigated different technological processes for treating discharged water from the oil and gas industries in the past several years, to the best of our knowledge, the total environmental analysis and its connection with the sustainability and innovation of advanced membrane technologies was not fully studied. In this review, papers consisting of non-industrial sources were excluded from the results and corresponding discussion sections. Hence, the aim of this review is to shed light on the grand challenges and limitations of different membrane technologies, with a focus on hybrid technological membrane systems as innovative approaches towards environmental sustainability in the purification of industrial wastewater.

\section{Materials and Methods}

\subsection{Review Protocol}

The review protocol followed to conduct the assessment of innovative membrane technologies included data from both Science Direct and Scopus databases. The combination of keywords was selected as per the following two categories:

- Technology-related terms: [innovative membrane technologies, water desalination, membrane distillation wastewater purification, industrial water discharge, wastewater treatment plants (WWTPS), produced wastewater, water processing].

- Sustainability-related terms: [environmental assessment, life cycle assessment, environmental sustainability, economic analysis].

In this research, the following flow-chart in Figure 2 was followed during the process of searching and selecting research articles that link sustainable membrane technologies with industrial produced water.

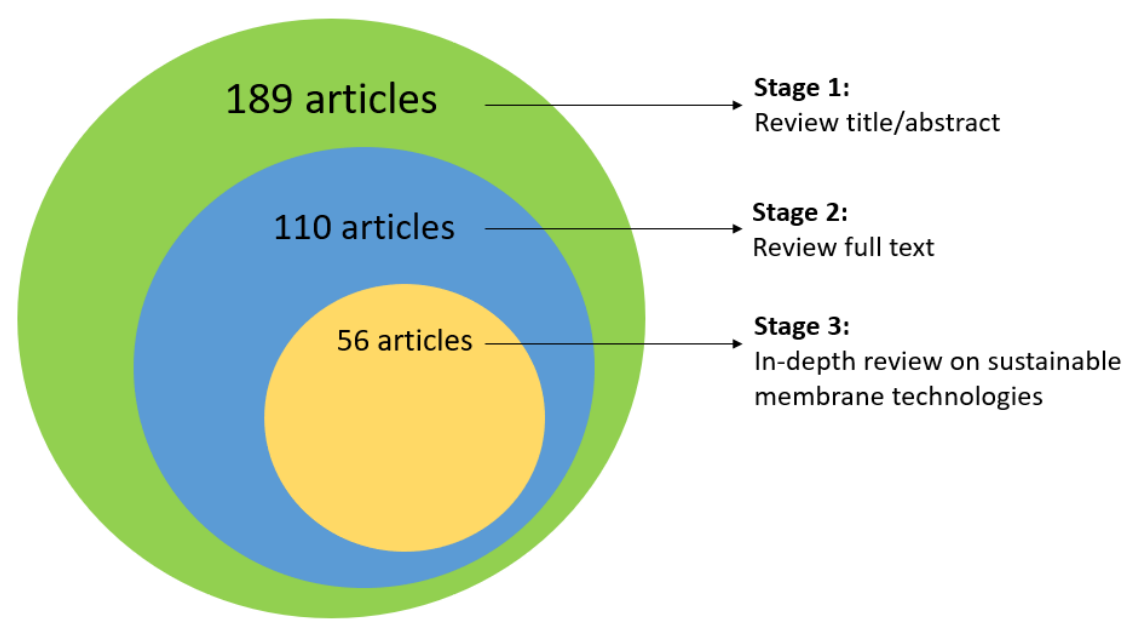

Figure 2. Step-by-step review schematic diagram.

\subsection{Research Data}

On the basis of our analysis of recent membrane technologies for treatment of oil and gas wastewater published yearly, as seen in Figure 3, it was found that most of the research was carried out in the United Stated, China, Spain, Germany, Italy, and Qatar. A number of 110 out of 189 publications were relevant to the aims of this work. Only $51 \%$ of these 
articles (56 publications) directly connected advanced membrane technologies with life cycle assessment and environmental sustainability in the fields of environmental science and engineering (Figure 4) of produced water. Of these, most were in the form of research articles (Figure 5). The other publications examined the use of polytetrafluoroethylene, polyvinylidene fluoride, polypropylene, and polystyrene, as well as polystyrene [32,43-53] in the application of water desalination and wastewater treatment. This review investigated many forms of new membrane technologies utilized for produced water treatment with a focus on technologies that are sustainable and innovative. The innovation section related to each of the technologies taken up is derived from the deep understanding of the literature and related publications in the domain of produced water treatment. A framework of new membrane technology for industrial wastewater was explored, with direct involvement with environmental and economic sustainability considerations, taking into account major obstacles and limitations in energy prices and environmental constraints.

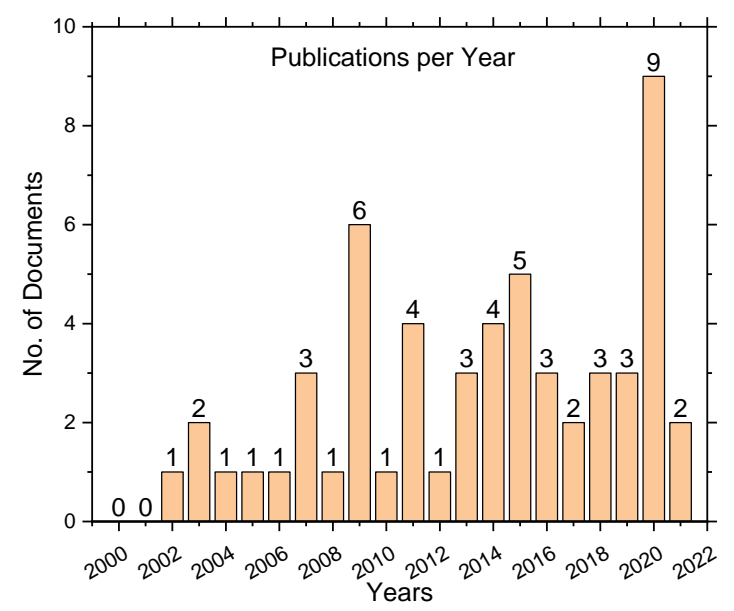

Figure 3. Publications relevant to produced water from 2000-2021.

No. of Documents vs Country and Subject Areas

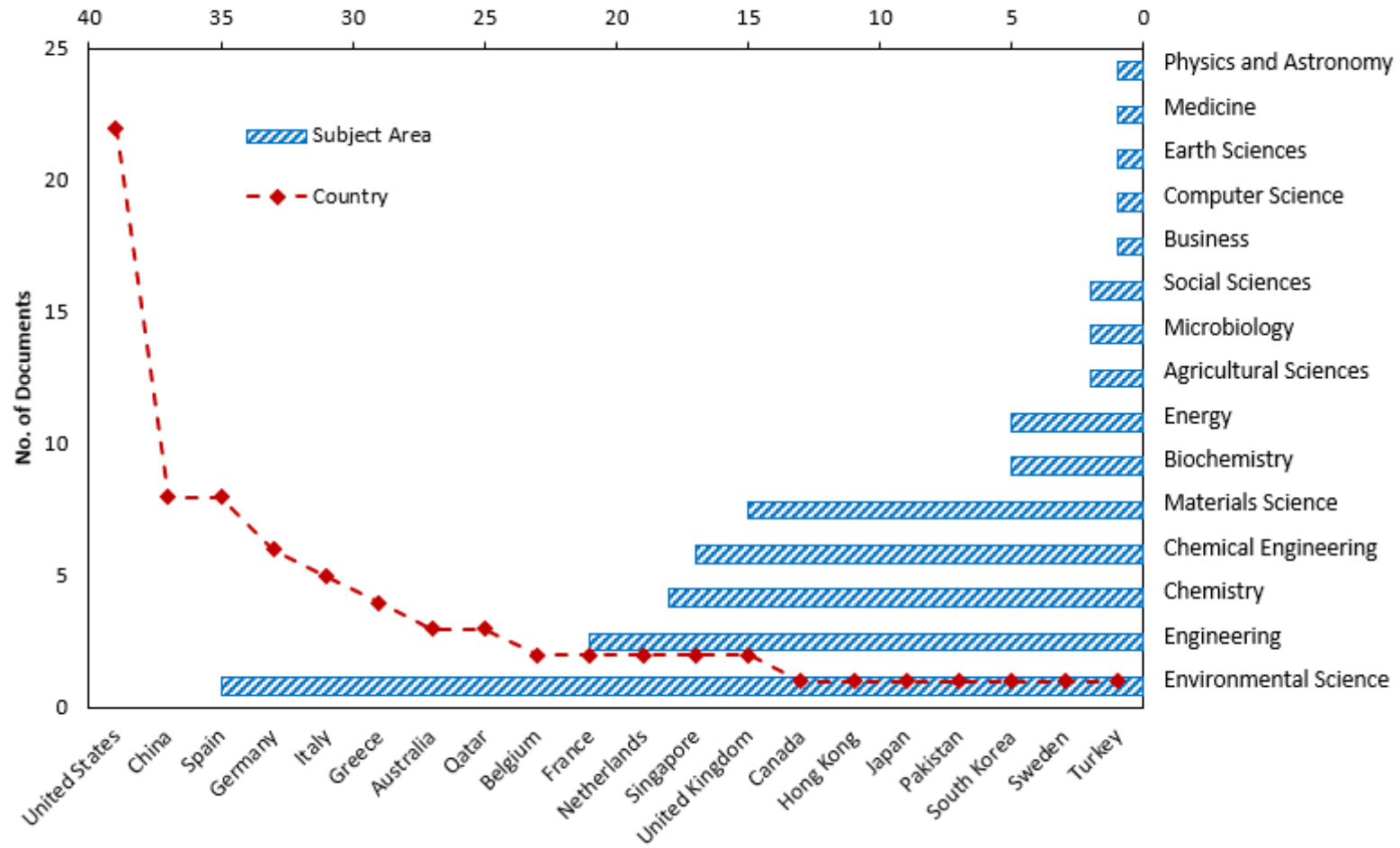

Figure 4. Number of documents published per country and subject area. 
(a)

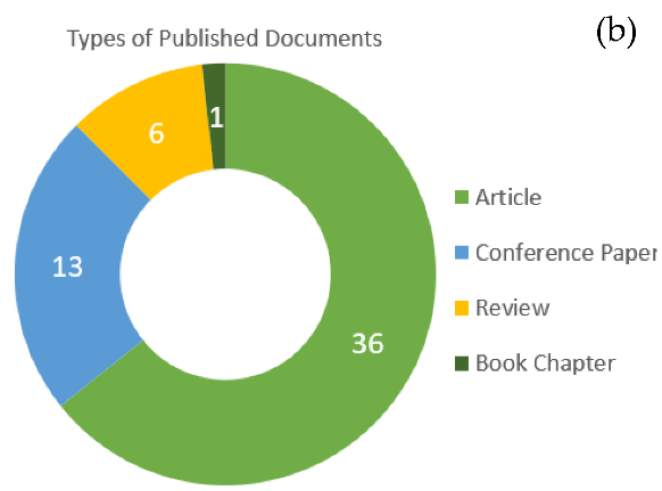

(b)

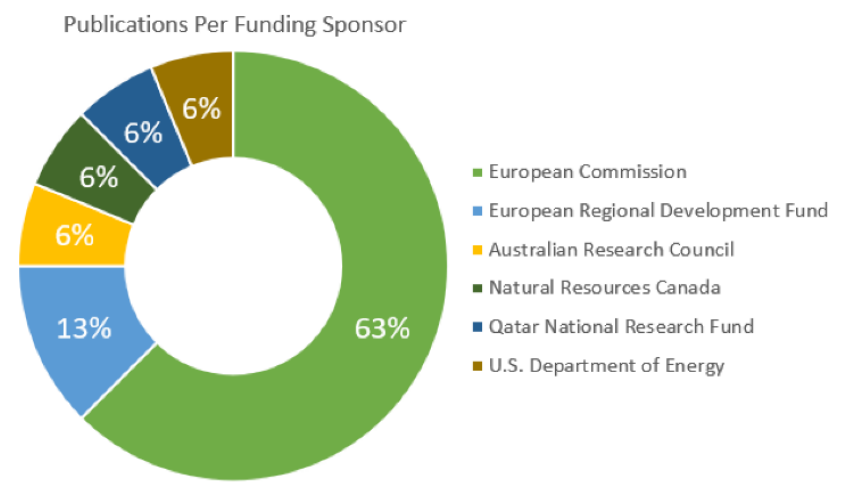

Figure 5. Pie-charts showing (a) the types of publications, and (b) the related articles published per funding sponsor.

\section{Results}

\subsection{Thermally-Driven Membrane Process}

Several research groups focused on membrane distillation (MD) of hydrophobic membranes for seawater desalination and wastewater treatment [43,45,46,54-56]. Membrane distillation is a well-known thermally driven process that utilizes the difference in vapor pressure, as the driving force, in generating purified permeate of improved quality. At the liquid-vapor interface of the hydrophobic membrane, a temperature gradient exists leading to a selective transport of substances from one side of the porous membrane to the other. For this reason, in MD, it is always preferred to have a non-wetted membrane with pore sizes ranging between $10 \mathrm{~nm}$ and $1 \mu \mathrm{m}$ [57].

A few groups mentioned in detail the preparation procedure of specific types of polymers used in membrane distillation $[58,59]$. New types of fabricated membrane were made using an electrospinning technique. The obtained membranes showed a micro grooved surface mimicking a lotus leaf structure. High permeability was achieved and consistent stability in membrane performance was attained. The results of this group were comparable with that in literature in terms of superior desalination performance. One group used the capillary flow porometer (CFP) to study the effect of fiber diameter and membrane thickness on the overall distribution of pore sizes of the developed membrane. Additionally, a contact angle meter (CAM) and gravimetric method exhibited the wettability of the prepared specimens. The output of the desalination process resulted in high flux rates. The water quality of membranes was compared with other commercially obtained membranes listed in the literature.

In another study, Li et al. [60] designed a novel membrane consisting of an irregular groove structure. Through analysis, the results showed higher membrane distillation performance. This was attributed to the morphological structure of the nano-scaled fibers within the membrane surface. Interestingly, an improved desalination performance was obtained with a high flux rate of $60 \mathrm{LMH}$. In comparison to typical commercial membranes mentioned in the literature, this result was outstanding. Wang et al. [61] presented a summary of recent studies on nanoporous membranes for removing water pollutants (i.e., salt, metallic ions, anions, nanoparticles, organic chemicals, and biological substrates). A number of review articles reported valuable summaries with referral to membrane properties in MD [61-66]. Table 3 lists the existing contaminants that can be eliminated using specific membrane technologies. 
Table 3. Contaminants in wastewaters and their corresponding membrane technologies.

\begin{tabular}{|c|c|c|c|c|}
\hline $\begin{array}{c}\text { Type of } \\
\text { Wastewater }\end{array}$ & Main Contaminants & Treatment Objectives & $\begin{array}{l}\text { Membrane } \\
\text { Technologies }\end{array}$ & Limitations \\
\hline Produced water & $\begin{array}{ll}- & \text { Drilling fluid additives } \\
\text { - } & \text { Oil and grease } \\
& \text { Divalent cations }\end{array}$ & $\begin{array}{ll}\text { - } & \text { Reduce salinity } \\
\text { Oily compounds } \\
\text { elimination }\end{array}$ & $\begin{array}{ll}\bullet & \mathrm{MD} \\
\bullet & \mathrm{FO} \\
\bullet & \mathrm{RO}\end{array}$ & $\begin{array}{ll}- & \text { Large water consumption } \\
- & \text { High total dissolved solids } \\
\text { - } & \text { Disposal regulations } \\
\text { - High membrane fouling }\end{array}$ \\
\hline $\begin{array}{l}\text { Municipal } \\
\text { wastewater }\end{array}$ & $\begin{array}{ll}\text { - } & \text { Microbial pathogens } \\
\text { - } & \text { Micropollutants } \\
\text { - } & \text { Amosphates } \\
\text { Ammonia }\end{array}$ & $\begin{array}{ll}\text { - } & \text { Degradable organic } \\
\text { - } & \text { Materials } \\
\text { - } & \text { Eliminiates nutrients }\end{array}$ & $\begin{array}{ll}\bullet & \mathrm{MF} \\
\bullet & \mathrm{UF} \\
\bullet & \mathrm{RO}\end{array}$ & $\begin{array}{ll}\text { - } & \text { Need for potable reuse } \\
\text { - } & \text { Large footprint } \\
\text { - } & \text { Treatment plant odor } \\
\text { High membrane fouling }\end{array}$ \\
\hline
\end{tabular}

MD: membrane distillation, FO: forward osmosis, NF: nanofiltration, RO: reverse osmosis.

\subsection{Pressure-Driven Membrane Process}

Forward osmosis (FO) is also a membrane-based technology that could find niche applications in the oil and gas PW treatment. Desalination using forward osmosis (FO) is an innovative method in which the natural osmotic pressure drives the system. The built-in deference in pressure between the feed solution (FS) and the draw solution (DS), which are separated by a semipermeable membrane, causes the movement of the solvent. The DS in the FO process plays the most important role, because it is the main source of movement and net force over the semi-permeable membrane.

In FO membranes, fouling in membrane processes is relatively low $[67,68]$ and can be even further minimized by optimizing the hydrodynamics [69]. Another benefit is the higher water recovery which helps to reduce the desalination brine (which is a major environmental problem) due to the high osmotic pressure difference across the FO membrane [70]. Additionally, some contaminants are rejected effectively using the FO membrane [71].

The combined electrocoagulation system (EC) and FO for generated water treatment was investigated by Sardari et al. This indicated that hybrid systems are feasible water recovery solutions [72]. Similarly, another group also studied a hybrid method in order to handle oily wastewater using an ozonation device before microfiltration. The results have shown that ozone pre-treatment could change the chemical nature of the emulsion of oil-in-water to increase membrane water weight. The PW model contains salt and, since it reduces membrane resistance and retains the need for chemical oxygen, is even more effective for pre-treatment [73].

\subsection{Hybrid Membrane Process}

A new method to boost the performance of FO desalination is to couple this process with other available desalination processes so that the hybrid process could have the advantages of both processes. Good examples of hybrid processes are forward osmosisreverse osmosis (FO-RO) and forward osmosis-microbial desalination cell (FO-MDC). FO desalination process could be coupled with $\mathrm{RO}$ desalination process as a pre-treatment step. In this case, the draw solution in $\mathrm{FO}$ would be the seawater with low salinity feedwater (wastewater) for dilution in FO process. As a result, the draw solution would reach the RO process for more processing as brackish water with low salinity which requires less energy due to the low osmotic pressure of the feedwater. This process is referred to as FO-RO hybrid system (Figure 6) [74]. 


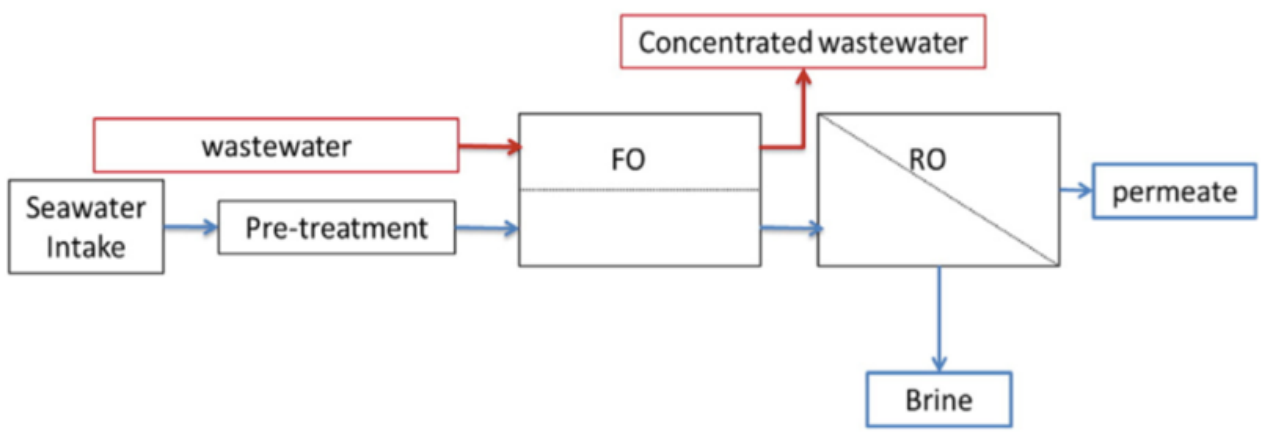

Figure 6. Hybrid FO-RO process with immersed FO membrane.

Pilot plant scales have confirmed that this configuration has shown a low fouling tendency and significant energy savings in comparison with RO desalination process. This process has been developed due to the lower irreversible fouling; FO is used as a pretreatment stage to make use of impaired water sources. Therefore, water transport occurs as the osmotic pressure of seawater is higher than the wastewater. After that, the diluted seawater is sent for SWRO to produce freshwater. A further treatment for effluent may be done for agricultural purposes. In this process the reclaimed wastewater is used as a feed for FO process. The produced dewatered waste which contains a vast amount of nutrients can be reused as fertilizer $[75,76]$.

\section{Discussion}

\subsection{Grand Challenges in Membrane Technology}

\subsubsection{Operational Cost Analysis}

Economic and cost assessments are vital to the maintenance of sustainable development targets regardless of complexity. A new evaluation system to further explore the resilience and efficiency of a wastewater treatment plant (WWTP) was recommended by Ba-Alawi [77]. Both efficiency curves and reliability coefficient (COR) have been calculated based on discharge requirements. Good examples of highly efficient separation process models were successfully presented [78,79].

OSPAR introduced a practical cost assessment approach for wastewater treatment [80]. The detailed evaluation of capital expenses (CAPEX) and operational expenses (OPEX) greatly depend on market vendors' endorsements. CAPEX estimated costs for PW treatment processes are represented in Figure 7. The treatment of extracted water from oil and gas wells accounts for a sizable portion of the operational costs of oil and gas wells. Each of the two primary protocols make use of current commercial technologies with varying degrees of efficacy in treating produced water. Any of the treatment processes remove oil, grease, and complete suspended solids, as well as salts, from the brines [81,82].

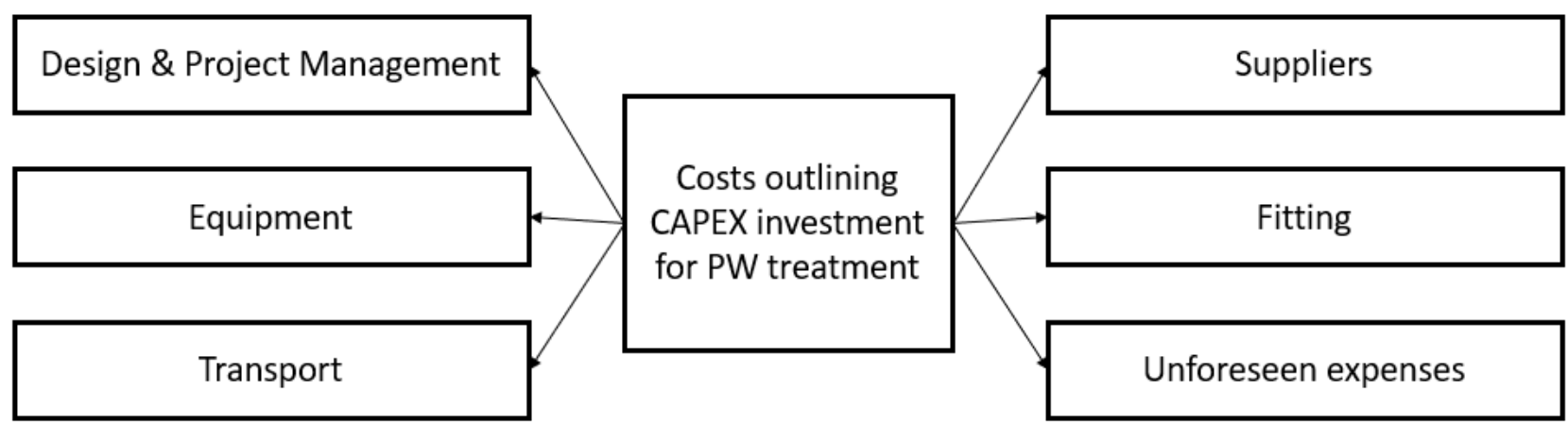

Figure 7. CAPEX representation for PW treatment processes. 
The oil and gas producing countries have a substitution advantage in that they can reuse drained water from oil and gas fields, thus preserving and expanding the size of green land for a longer time. Simultaneously, in terms of economic advantage, the amount of water provided by the oil and gas industry is five times that of commercially produced oil from the same resource in the region $[83,84]$.

Table 4 shows how the type of wastewater and its chemical components, in addition to the location and size of the industrial entity, greatly affect the disposal expenses of produced water disposal [85].

Table 4. Estimated costs for produced water disposal [85].

\begin{tabular}{|c|c|c|c|}
\hline Method & Cost $(\$ / b b l)$ & Limitations & Benefits \\
\hline Surface discharge & $0.01-0.08$ & Energy costs & Livestock, irrigation \\
\hline Secondary recovery & $0.05-1.25$ & Infrastructure & Increase production \\
\hline Commercial water hauling & $0.01-5.50$ & Distance & 1 \\
\hline Shallow reinjection & $0.10-1.33$ & Energy and maintenance & Recharge aquifer \\
\hline Evaporation pits & $0.01-0.80$ & Soil contamination & Livestock impoundment \\
\hline Constructed wetland & $0.001-2.00$ & Land area & Communities, education \\
\hline
\end{tabular}

In contrast, wastewater that is recycled using new, low-cost technology is combined with PW, which improves the water's consistency and prevents long-term hardening of agricultural soil [86]. As a result, this strategy would result in an expansion of the green land in oil-producing countries. In exchange, the population in the area surrounding the green land would rise, resulting in social and economic growth. The more economically viable it becomes, the more employment and services are attracted to the region. This, by default, leads to a beneficial effect on the socioeconomic status of the community, resulting in an increase in their social expectations $[87,88]$.

\subsubsection{Energy Consumption of Membrane Systems}

It was discovered by a research group that raising the feed pressure up to $6.586 \mathrm{MPa}$ significantly lowered the specific energy consumption (SEC) to $0.323 \mathrm{~kW} \mathrm{~h} / \mathrm{m}^{3}$ in the system with two energy recovery devices. Freshwater supplied from RO system makes it beneficial in arid areas [89]. Given that $40 \%$ of the world's population are $100 \mathrm{~km}$ away from a seawater source, much research has been made on the different desalination technologies to reduce the capital and operational costs. Currently, the operating costs and energy requirements for desalination using reverse osmosis and thermal distillation are $0.5-1.2$ (USD/day. $\mathrm{m}^{3}$ ) and $0.8-1.5\left(\mathrm{USD} / \mathrm{m}^{3}\right)$, respectively. In contrast, the energy cost of former techniques is about $4-5\left(\mathrm{kWhelec} / \mathrm{m}^{3}\right)$ and $10-16\left(\mathrm{kWhelec} / \mathrm{m}^{3}\right)$ respectively [74]. This means that the desalination technologies are very energy intensive.

\subsubsection{Environmental Analysis}

The main three key factors necessary for sustainable growth are the economy, environment, and society [90]. This also applies to wastewater disposal. However, each wastewater treatment system has environmental consequences that can have an effect on the ecosystem's efficiency, social health, and resource use [91]. These may have either a beneficial or detrimental effect on the surrounding ecosystem [92]. As a result, an effort must be made to evaluate the causes and consequences of these impacts [93]. In order to mitigate the environmental impacts of wastewater treatment plants, it is important to understand the system's entire life cycle in addition to design considerations [94].

A study was conducted to investigate the environmental consequences of irrigation using produced water. This group established a solid foundation upon which the petroleum industry would estimate the risks associated with crop watering using generated water. As a result, this study's results directly favor the re-use of PW in water-scarce regions. In the United States, the use of PW in agricultural applications is authorized [95]. The tailings 
development and function of the plant are depicted in Figure 8, as they fall under the system boundaries of the life cycle inventory $[84,96]$.

\section{Emissions out}

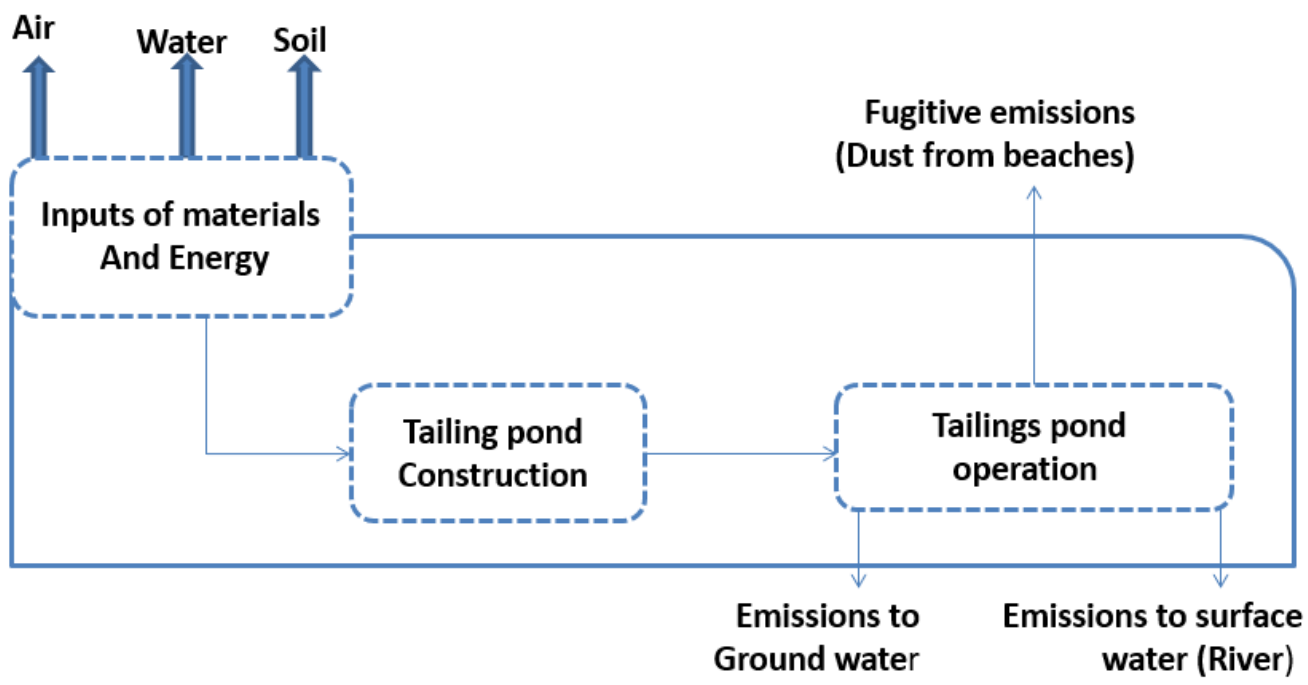

Figure 8. System boundaries of the Life Cycle Inventory.

The Life Cycle Assessment (LCA) enables the evaluation of a system's environmental impact and its relationships with the environment by considering the system's entire life cycle, which includes pre-processing points (sources of raw materials), production, circulation, use (both maintenance and reuse), recycling, and final discharge [97]. The aim of life cycle assessments is to evaluate the consequences of a product or system's interactions with the environment. Thus, it assesses the environmental impacts of a commodity or system's use, either consciously or indirectly. LCA mainly evaluates the environmental impact of a product or device from the source of its raw elements to production and, if applicable, during its life cycle, up to its disposal and clearance. The midpoint methodology focuses entirely on the different groups of environmental effects [98].

A group previously examined the environmental effects of traditional wastewater treatment plants (WWTPs) and concluded that energy recycling would make a substantial contribution to the overall value of the ecosystem (71 percent) [99]. The LCA approach has been used as an assessment verification technique in sustainable water management because it offers useful knowledge on the different environmental impacts of actual or anticipated water-related infrastructure and processes. The LCA has difficulty studying water systems due to the following factors: a) system structure and challenges in defining system boundaries; b) the complexity of the LCA methodology; and c) data availability problems. Several LCA review experiments are based on site-specific conventions, with varying choices for the LCIA approach and LCA structures [100]. Certain research introduced LCA practices integrate economic metrics when evaluating the efficiency of water systems, filtering the effect categories through the use of appropriate indicators and weighting scales to provide a true and dependable environmental impact evaluation [79].

Additionally, it was confirmed that cost-effective water storage is a critical component of the oil and gas industry's efforts to ensure improved safe activity in the industry. Due to the unpredictable characteristics of produced water, an ideal and optimum combination of different technologies must be developed to ensure that adequate treatment can be used [101].

Another study states that the quality of produced water is frequently a constraint on its reuse in irrigation, as it can influence soil salinity. Attempts are being made to comprehend the primary environmental and economic conditions, as well as the life cycle 
evaluation, that can encourage the advancement of irrigation with treated processed water in dry lands throughout the world [83,102].

\subsection{Limitations and Constraints of Membrane Technology}

\subsubsection{Energy Usage and Costs}

Membrane technologies that are thermally-driven based can treat large capacities of seawater, up to $55,000 \mathrm{~m}^{3}$ /day, while the membrane technology plants can treat 500$5000 \mathrm{~m}^{3}$ / day of seawater depending on the size of the treatment plant. Current patterns show that membrane distillation costs are declining as a direct result of economies of scale (enormous plants). The specialists suggested that every case should be assessed carefully before choosing the technology for treatment with membrane processes as being the most versatile and promising technology for future applications [103].

The expenses of desalination rely principally upon the sort of desalination process utilized, the nature of the influent and effluent, the yield limit of the plant, and the accessible choices for waste removal. The overall cost includes the cost of removal, labor, investment in land and equipment, operational and maintenance, energy consumption, and environmental costs [104].

Table 5 shows a comparison between the thermal and membrane technology methods. The highest costs are attributed to the capital and electricity costs. Thermally-driven membrane processes are more expensive than pressure-driven ones. Thus, membrane technology is considered a feasible method for saline water treatment [105]. However, the total costs can be further reduced depending on the size of the treatment plant. A smaller plant will require less labor and less energy compared to a large plant [106].

Table 5. Different desalination techniques and the associated costs.

\begin{tabular}{ccc}
\hline \multirow{2}{*}{ cost Parameter } & \multicolumn{2}{c}{ Membrane Technology } \\
\cline { 2 - 3 } & Thermally-Driven & Pressure-Driven \\
\hline Capital cost $\left(\mathrm{US} \$ / \mathrm{m}^{3}\right)$ & 0.449 & 0.301 \\
\hline Energy $\left(\mathrm{US} \$ / \mathrm{m}^{3}\right)$ & 0.555 & $0.25-0.27$ \\
\hline Labour $\left(\mathrm{US} \$ / \mathrm{m}^{3}\right)$ & 0.128 & 0.128 \\
\hline Chemicals $\left(\mathrm{US} \$ / \mathrm{m}^{3}\right)$ & $0.024-0.045$ & $0.018-0.054$ \\
\hline Membrane replacement $\left(\mathrm{US} \$ / \mathrm{m}^{3}\right)$ & 0 & $0.001-0.072$ \\
\hline Maintenance $\left(\mathrm{US} \$ / \mathrm{m}^{3}\right)$ & $0.018-0.032$ & $0.018-0.032$ \\
\hline Total costs $\left(\mathrm{US} \$ / \mathrm{m}^{3}\right)$ & $1.10-1.15$ & $0.45-0.877$ \\
\hline
\end{tabular}

\subsubsection{Environmental Constraints}

The main environmental concern that is associated with all desalination processes is the energy intensity. Energy as either electricity or steam produced using non-renewable sources of energy leads to gas emissions. For example, $1 \mathrm{~m}^{3}$ of desalinated water by generally requires $1 \mathrm{~L}$ of fuel. The other environmental issue is the brine and its disposal which affects the marine life. No detailed environmental impact assessments for a desalination plant is yet provided; however, the above environmental concerns should be addressed and mitigated as required [107].

\subsection{Sustainable Innovation in Membrane Technology}

A microbial desalination cell (MDC) is a bio-electrochemical cell in which the wastewater can be treated while desalinating water and producing electrical energy from a renewable energy source [108-111]. A typical MDC includes an anion exchange selective membrane (AEM). The membrane used for MDC can be replaced by FO membrane producing FO-MDC hybrid technology. The concentrated feedwater of FO is introduced to the MDC cathode chamber, for COD removal, while the diluted draw solution is desali- 
nated in MDC salt chamber. Comparing MDC process standalone process with MDC-FO shows that the latter process reduces the saline water conductivity, thus decreasing the total dissolved solids (TDS) generally. Research also shows that the FO-MDC process is a promising technology for pre-desalination treatment for highly saline wastewater. FO-MDC process enhances the chemical oxygen demand (COD) removal. The system is shown in Figure 9 [112-115].

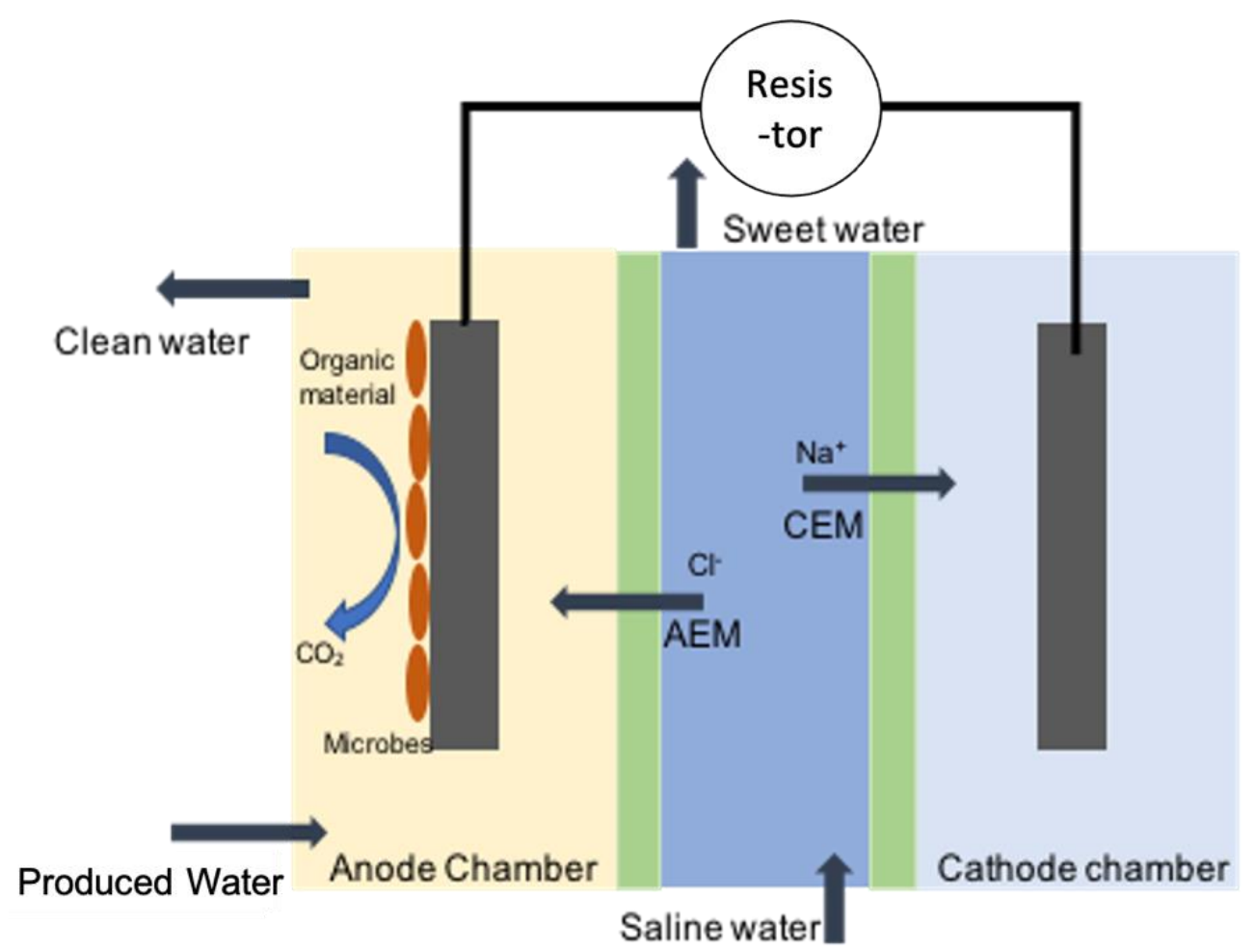

Figure 9. Microbial desalination cell for produced water treatment.

\subsubsection{Mechanism of Sustainable Technology}

A typical MDC includes three chambers, with an anode cathode and salt chamber in the middle. The salt chamber is separated from the anode by an anion exchange selective membrane (AEM), and separated from the cathode by a cation exchange selective membrane (CEM). Anodophelic microorganisms in the anode chamber oxidize the organic matter (reducing the COD and treating wastewater) in the anode chamber, producing electrons traveling through the outer circuit. This process reduces the electron acceptor in the cathode chamber [116-118]. As a result, a driving force is created, stimulating anions and cations in saline water to be separated, resulting in pure or semi-pure water. In the coupled MDC-FO, the anode effluent from MDC is used as the FO feed; after that, clean water is extracted. The concentrated wastewater of FO is introduced to the MDC cathode chamber for COD removal, while the diluted draw solution is desalinated in the MDC salt chamber [119-121].

\subsubsection{Feasibility of the Hybrid System}

In order to check the feasibility and the performance of this hybrid system, the impact of initial COD concentration, hydraulic retention time (HRT), and salt concentration have been investigated [122].

The FO process only removed about $10 \%$ of COD. This is because the small molecules move through the FO membrane, which causes fouling of the membrane, affecting the water flux and COD removal as well, while the MDC-FO removed almost $80 \%$ of COD, which is very close to MDC standalone. The conductivity reduction was about $30 \%$ for MDC alone and $60 \%$ for FO process alone, while for coupled system MDC-FO it was about 
$80 \%$. Additionally, the effluent volume of the MDC-FO system was reduced by $64 \%$ due to water flux in the FO. On the other hand, a 14\% reduction of the effluent volume of the standalone MDC was caused by evaporation on its cathode. The enhanced desalination of the MDC-FO system was mainly due to the dilution in the coupled FO cell, which contributed $62 \%$ of the conductivity reduction, as the standalone FO process reduced the conductivity 1.5 times more than the standalone MDC [123-125]. The performance of MDC-FO process over FO and MDC was assessed as follows:

It can be seen from Table 6 that the MDC-FO gave a better COD removal than MDC, while MDC-FO gave water recovery and the rate of decrease in TDS values in between of FO and MDC standalone cells. MDC-FO has properties in between of FO and MDC [126]. Bioremediation of PW can be achieved by this technology. PW contains organic residuals and wastes; these residuals can be treated as a substrate for the microbial population in the anode chamber. This can be achieved only by changing the type of influent treated wastewater to be PW [127]. This is an efficient technique to lower the organic content of $\mathrm{PW}$. This reduces in turn the energy requirement for PW treatment as the system does not require any energy for aeration, enables the reuse of water in addition to desalting water, and produces less sludge compared to other biological processes [127].

Table 6. Performance of different cells under at $675 \mathrm{ppm}$ COD at room temperature [126].

\begin{tabular}{cccc}
\hline Cell & COD Removal \% & Water Recovery $(\mathbf{m L})$ & The rate of Decrease in TDS $(\mathrm{g} / \mathrm{L} . \mathbf{d})$ \\
\hline MDC-FO & $43.7 \pm 1.3$ & $153.6 \pm 6.7$ & $22.7 \pm 5.3$ \\
\hline MDC & $40.2 \pm 2.5$ & - & $11.2 \pm 0.3$ \\
\hline FO & - & $166.4 \pm 6.2$ & $20.1 \pm 0.0$ \\
\hline
\end{tabular}

\subsubsection{Future Potential Applications}

Despite the fact that this subject needs more investigation and more research, this is a short review of how the MDC is used in irrigation. Animal manure which is rich in organic material can be used as a substrate for MDC-FO for the energy recovery. This can be diluted further by the draw solution till reaching the agriculture standards in FO system. However, the draw solution has to be a concentrated fertilizer solution, so that the draw solution does not need regeneration later which will save energy. Additionally, MDC coupled with FO can produce electricity. The produced electricity per dry manure is $9.2 \mathrm{~mW} / \mathrm{kg}$. Beside the electricity production, the animal manure contains a good amount of matter which is very crucial for plant growth such as nitrogen, phosphorus, and potassium. In addition, reusing the animal manure saves the environment from pollution and makes this as a sustainable substrate source for MDC as well as a sustainable fertilizer [128-132].

\section{Future Perspective}

Using membrane technologies for PW treatment is an active area of research to bring about energy efficient treatment processes. The future of this technology should be directed to develop novel material for membrane fabrication which can tolerate the fouling issues while requiring less energy. Hybrid and biological processes can be another area of investment. Membrane bioreactor, microbial fuel cells, and microbial desalination cells coupled with forward osmosis membrane technology can enhance the efficiency of PW treatment, while producing pure potable water and renewable energy. This requires more investigation into type of draw solutions to make forward osmosis process cost-effective while choosing an optimum bacterial culture with suitable conditions [133]. Optimizing and commercializing such systems is a must in order to be applied on larger scales. Additionally, inspection in pre-treatment processes prior to PW treatment using membrane technologies is recommended [134]. This can be achieved by applying some primary sieving treatment coupled with the addition of some chemical additives to aggulate unprecipitated matter and remove it with other large particulate matter, controlling the fouling [135]. Finally, the best and most sustainable membrane process which can be applied for PW treatment 
is the membrane that is optimized for that specific kind of PW [136]. This is due to PW quality dependence on the geology of the oil well that it is produced from [137].

\section{Conclusions}

Due to the extremely strong global demand for the extraction and refining of oil and gas, discharged wastewater will continue to be released into surface water. Therefore, appropriate treatment is required for its reuse or safe release back to surface waters. To ensure that proper wastewater treatment takes place, optimal combinations of various membrane technologies must be implemented. Current advancements in membrane technologies were discussed for both thermally-driven and pressure-driven membrane processes. For hybrid systems, FO-RO process has been addressed with the advancements coupled with it. Hybrid systems such as FO-MDC were considered as novel forms of membrane processes that are both innovative and sustainable, due to readiness of renewable sources required for energy production in water desalination and wastewater treatment. The LCA is an effective instrument not only to evaluate the environmental effects of different produced water treatment systems but also to evaluate the overall efficiency of economic indicators. Environmental, financial, and social factors should be balanced in the process of achieving successful wastewater treatment. Various limitations exist in different membrane technologies as in energy costs and environmental constraints. Generally, the costs of achieving the desired water quality can vary depending on the geographical location of the membrane technological system and can be greatly affected by the characteristics of the feed wastewater. In locations where water supplies are scarce, the use of treated produced water in irrigation will provide social, economic, and environmental benefits, only if the desalination sector is well-developed.

Author Contributions: H.A. is responsible for the main body of text drafting, data collection, and analysis as part of PhD dissertation and GSRA funding. P.E., A.K. and H.M.A. contributed equality in some sections in the first draft. H.A. structured the writing of the original draft manuscript. M.K. fund acquisition, project supervision (QUCG-21/22-4), and draft revision. All authors have read and agreed to the published version of the manuscript.

Funding: The work was possible by the grant funded by Qatar University Grant number: QUCG21/22-4; Project number 1008280.

Institutional Review Board Statement: Not applicable.

Informed Consent Statement: Not applicable.

Data Availability Statement: Not applicable.

Acknowledgments: The work was funded by Qatar University Grant number: QUCG-21/22-4; Project number 1008280 and the Award [GSRA5-1-0524-18068] from the Qatar National Research Fund (A Member of The Qatar Foundation). The contents herein are solely the responsibility of the authors.

Conflicts of Interest: The authors declare no conflict of interest. The funders had no role in the design of the study; in the collection, analyses, or interpretation of data; in the writing of the manuscript; or in the decision to publish the results.

\section{References}

1. Ibrahim, T.H.; Sabri, M.A.; Khamis, M.I. Application of multiwalled carbon nanotubes and its magnetite derivative for emulsified oil removal from produced water. Environ. Technol. 2019, 40, 3337-3350. [CrossRef]

2. Estrada, J.M.; Bhamidimarri, R. A review of the issues and treatment options for wastewater from shale gas extraction by hydraulic fracturing. Fuel 2016, 182, 292-303. [CrossRef]

3. Clay, L.; Pichtel, J. Treatment of Simulated Oil and Gas Produced Water via Pilot-Scale Rhizofiltration and Constructed Wetlands. Int. J. Environ. Res. 2019, 13, 185-198. [CrossRef]

4. Mohammed, T.; Abbas, E.; Ahmed, T. Turbidity and oil removal from oilfield produced water, middle oil company by electrocoagulation technique. In Proceedings of the MATEC Web of Conferences. EDP Sci. 2018, 162, 5010.

5. Li, L.; Al-Muntasheri, G.A.; Liang, F. A review of crosslinked fracturing fluids prepared with produced water. Petroleum 2016, 2, 313-323. [CrossRef] 
6. Faksness, L.G.; Grini, P.G.; Daling, P.S. Partitioning of semi-soluble organic compounds between the water phase and oil droplets in produced water. Mar. Pollut. Bull. 2004, 48, 731-742. [CrossRef]

7. Frid, C. Bioaccumulation in Marine Organisms. Effect of Contaminants from Oil Well Produced Water. Org. Geochem. 2003, 34, 149. [CrossRef]

8. Tibbetts, P.J.C.; Buchanan, I.T.; Gawel, L.J.; Large, R. A Comprehensive Determination of Produced Water Composition. Prod. Water 1992, 97-112. [CrossRef]

9. Fathima, A.; Almohsin, A.; Michael, F.M.; Bataweel, M.; Alsharaeh, E.H. Polymer nanocomposites for water shutoff application-A review. Mater. Res. Express 2018, 6, 32001. [CrossRef]

10. Esmaeilirad, N.; Carlson, K.; Ozbek, P.O. Influence of softening sequencing on electrocoagulation treatment of produced water. J. Hazard. Mater. 2015, 283, 721-729. [CrossRef]

11. Sappington, E.N.; Rifai, H.S. Low-frequency electromagnetic treatment of oilfield produced water for reuse in agriculture: Effect on water quality, germination, and plant growth. Environ. Sci. Pollut. Res. 2018, 25, 34380-34391. [CrossRef]

12. Smith, A.P.; Van De Ven, C.J.C.; Richardson, S.D. Current water management practices, challenges, and innovations for US unconventional oil and gas development. Curr. Sustain. Energy Rep. 2017, 4, 209-218. [CrossRef]

13. Bakke, T.; Klungsøyr, J.; Sanni, S. Environmental impacts of produced water and drilling waste discharges from the Norwegian offshore petroleum industry. Mar. Environ. Res. 2013, 92, 154-169. [CrossRef]

14. Giri, S.S.; Harshiny, M.; Sen, S.S.; Sukumaran, V.; Park, S.C. Production and characterization of a thermostable bioflocculant from Bacillus subtilis F9, isolated from wastewater sludge. Ecotoxicol. Environ. Saf. 2015, 121, 45-50. [CrossRef]

15. He, K.; Borthwick, A.G.; Lin, Y.; Li, Y.; Fu, J.; Wong, Y.; Liu, W. Sale-based estimation of pharmaceutical concentrations and associated environmental risk in the Japanese wastewater system. Environ. Int. 2020, 139, 105690. [CrossRef]

16. Pica, N.E.; Carlson, K.; Steiner, J.J.; Waskom, R. Produced water reuse for irrigation of non-food biofuel crops: Effects on switchgrass and rapeseed germination, physiology and biomass yield. Ind. Crop. Prod. 2017, 100, 65-76. [CrossRef]

17. Dolan, F.C.; Cath, T.Y.; Hogue, T.S. Assessing the feasibility of using produced water for irrigation in Colorado. Sci. Total Environ. 2018, 640-641, 619-628. [CrossRef]

18. Quist-Jensen, C.A.; Macedonio, F.; Drioli, E. Membrane technology for water production in agriculture: Desalination and wastewater reuse. Desalination 2015, 364, 17-32. [CrossRef]

19. Lyu, S.; Chen, W.; Zhang, W.; Fan, Y.; Jiao, W. Wastewater reclamation and reuse in China: Opportunities and challenges. J. Environ. Sci. 2016, 39, 86-96. [CrossRef]

20. Zoubeik, M.; Ismail, M.; Salama, A.; Henni, A. New developments in membrane technologies used in the treatment of produced water: A review. Arab. J. Sci. Eng. 2018, 43, 2093-2118. [CrossRef]

21. Oshinowo, L.M.; Quintero, C.G.; Vilagines, R.D. CFD and population balance modeling of crude oil emulsions in batch gravity separation-comparison to ultrasound experiments. J. Dispers. Sci. Technol. 2016, 37, 665-675. [CrossRef]

22. Liu, Y.; Cheng, Q.; Zhang, B.; Tian, F. Three-phase hydrocyclone separator-A review. Chem. Eng. Res. Des. 2015, 100, 554-560. [CrossRef]

23. Ashoor, B.B.; Mansour, S.; Giwa, A.; Dufour, V.; Hasan, S.W. Principles and applications of direct contact membrane distillation (DCMD): A comprehensive review. Desalination 2016, 398, 222-246. [CrossRef]

24. Jepsen, K.; Hansen, L.; Mai, C.; Yang, Z. Challenges of membrane filtration for produced water treatment in offshore oil \& gas production. In Proceedings of the OCEANS 2016 MTS/IEEE Monterey, Monterey, CA, USA, 19-23 September 2016; pp. 1-8.

25. Gurreri, L.; Cipollina, A.; Tamburini, A.; Micale, G. Electrodialysis for wastewater treatment-Part II: Industrial effluents. In Current Trends and Future Developments on (Bio-) Membranes; Elsevier: Amsterdam, The Netherlands, 2020; pp. 195-241.

26. Azeez, R.A. Removal oil from produced water by using adsorption method with adsorbent a Papyrus reeds. Eng. Technol. J. 2019, 37, 157-165.

27. Progress on Drinking Water, Sanitation and Hygiene: 2017 Update and SDG Baselines; World Health Organization (WHO) and the United Nations Children's Fund (UNICEF): Geneva, Switzerland, 2017.

28. Kargari, A.; Shirazi, M.J.A. Direct contact membrane distillation for seawater desalination AU—Shirazi, Mohammad Mahdi A. Desalin. Water Treat. 2012, 49, 368-375. [CrossRef]

29. Piesse, M. Global Water Supply and Demand Trends Point Towards Rising Water Insecurity; Future Directions International: Nedlands, Australia, 2020.

30. Annual Report 2019; Qatar Electricity \& Water Co.: Doha, Qatar, 2019.

31. Mondal, S.; Wickramasinghe, S.R. Produced water treatment by nanofiltration and reverse osmosis membranes. J. Memb. Sci. 2008, 322, 162-170. [CrossRef]

32. Liao, Y.; Wang, R.; Tian, M.; Qiu, C.; Fane, A.G. Fabrication of polyvinylidene fluoride (PVDF) nanofiber membranes by electro-spinning for direct contact membrane distillation. J. Memb. Sci. 2013, 425-426, 30-39. [CrossRef]

33. Lokare, O.R.; Tavakkoli, S.; Wadekar, S.; Khanna, V.; Vidic, R.D. Fouling in direct contact membrane distillation of produced water from unconventional gas extraction. J. Memb. Sci. 2017, 524, 493-501. [CrossRef]

34. Kim, J.; Kwon, H.; Lee, S.; Lee, S.; Hong, S. Membrane distillation (MD) integrated with crystallization (MDC) for shale gas produced water (SGPW) treatment. Desalination 2017, 403, 172-178. [CrossRef]

35. Xiong, B.; Zydney, A.L.; Kumar, M. Fouling of microfiltration membranes by flowback and produced waters from the Marcellus shale gas play. Water Res. 2016, 99, 162-170. [CrossRef] 
36. Zhang, Z.; Du, X.; Carlson, K.H.; Robbins, C.A.; Tong, T. Effective treatment of shale oil and gas produced water by membrane distillation coupled with precipitative softening and walnut shell filtration. Desalination 2019, 454, 82-90. [CrossRef]

37. Abdelrazeq, H.; Khraisheh, M.; Al Momani, F.; McLeskey, J.T.; Hassan, M.K.; Gad-el-Hak, M.; Tafreshi, H.V. Performance of electrospun polystyrene membranes in synthetic produced industrial water using direct-contact membrane distillation. Desalination 2020, 493, 114663. [CrossRef]

38. Esteves, R.J.A.; Gornick, V.; Alqurwani, D.S.; Koenig-Lovejoy, J.; Abdelrazeq, H.; Khraisheh, M.; Forzano, A.V.; Gad-el-Hak, M.; Tafreshi, H.V.; McLeskey, J.T. Activated carbon-doped polystyrene fibers for direct contact membrane desalination. Emergent Mater. 2020, 3, 807-814. [CrossRef]

39. Alkhouzaam, A.; Qiblawey, H.; Khraisheh, M. membranes Polydopamine Functionalized Graphene Oxide as Membrane Nanofiller: Spectral and Structural Studies. Membranes 2021, 11, 86. [CrossRef] [PubMed]

40. Akyon, B.; Lipus, D.; Bibby, K. Glutaraldehyde inhibits biological treatment of organic additives in hydraulic fracturing produced water. Sci. Total Environ. 2019, 666, 1161-1168. [CrossRef] [PubMed]

41. Lutzu, G.A.; Dunford, N.T. Algal treatment of wastewater generated during oil and gas production using hydraulic fracturing technology. Environ. Technol. 2019, 40, 1027-1034. [CrossRef]

42. Akhbarizadeh, R.; Moore, F.; Mowla, D.; Keshavarzi, B. Improved waste-sourced biocomposite for simultaneous removal of crude oil and heavy metals from synthetic and real oilfield-produced water. Environ. Sci. Pollut. Res. 2018, 25, 31407-31420. [CrossRef]

43. Cho, H.; Choi, Y.; Lee, S. Effect of pretreatment and operating conditions on the performance of membrane distillation for the treatment of shale gas wastewater. Desalination 2018, 437, 195-209. [CrossRef]

44. Lee, J.; Kim, Y.; Kim, W.; Francis, L.; Amy, G.; Ghaffour, N. Performance modeling of direct contact membrane distillation (DCMD) seawater desalination process using a commercial composite membrane. J. Memb. Sci. 2015, 478, 85-95. [CrossRef]

45. Ke, H.; Feldman, E.; Guzman, P.; Cole, J.; Wei, Q.; Chu, B.; Alkhudhiri, A.; Alrasheed, R.; Hsiao, B.S. Electrospun polystyrene nanofibrous membranes for direct contact membrane distillation. J. Memb. Sci. 2016, 515, 86-97. [CrossRef]

46. Khayet, M.; Wang, R. Mixed Matrix Polytetrafluoroethylene/Polysulfone Electrospun Nanofibrous Membranes for Water Desalination by Membrane Distillation. ACS Appl. Mater. Interfaces 2018, 10, 24275-24287. [CrossRef]

47. Wang, P.; Chung, T.S. Recent advances in membrane distillation processes: Membrane development, configuration design and application exploring. J. Memb. Sci. 2015, 474, 39-56. [CrossRef]

48. Cong, H.; Chuai, D.; Chul, Y.; Kyong, H.; Duc, L. A novel electrospun, hydrophobic, and elastomeric styrene-butadiene-styrene membrane for membrane distillation applications. J. Memb. Sci. 2018, 549, 420-427. [CrossRef]

49. Wang, K.; Hou, D.; Wang, J.; Wang, Z.; Tian, B.; Liang, P. Applied Surface Science Hydrophilic surface coating on hydrophobic PTFE membrane for robust anti-oil-fouling membrane distillation. Appl. Surf. Sci. 2018, 450, 57-65. [CrossRef]

50. Lee, E.J.; An, A.K.; Hadi, P.; Lee, S.; Woo, Y.C.; Shon, H.K. Advanced multi-nozzle electrospun functionalized titanium dioxide/polyvinylidene fluoride-co-hexafluoropropylene (TiO2/PVDF-HFP) composite membranes for direct contact membrane distillation. J. Memb. Sci. 2017, 524, 712-720. [CrossRef]

51. Lalia, B.S.; Guillen-Burrieza, E.; Arafat, H.A.; Hashaikeh, R. Fabrication and characterization of polyvinylidenefluoride-cohexafluoropropylene (PVDF-HFP) electrospun membranes for direct contact membrane distillation. J. Memb. Sci. 2013, 428, 104-115. [CrossRef]

52. Lalia, B.S.; Guillen, E.; Arafat, H.A.; Hashaikeh, R. Nanocrystalline cellulose reinforced PVDF-HFP membranes for membrane distillation application. Desalination 2014, 332, 134-141. [CrossRef]

53. Essalhi, M.; Khayet, M. Self-sustained webs of polyvinylidene fluoride electrospun nanofibers at different electrospinning times: 1. Desalination by direct contact membrane distillation. J. Memb. Sci. 2013, 433, 167-179. [CrossRef]

54. Al-Obaidani, S.; Curcio, E.; Macedonio, F.; Di Profio, G.; Al-Hinai, H.; Drioli, E. Potential of membrane distillation in seawater desalination: Thermal efficiency, sensitivity study and cost estimation. J. Memb. Sci. 2008, 323, 85-98. [CrossRef]

55. Liang, B.; Pan, K.; Li, L.; Giannelis, E.P.; Cao, B. High performance hydrophilic pervaporation composite membranes for water desalination. Desalination 2014, 347, 199-206. [CrossRef]

56. Chew, N.G.P.; Zhao, S.; Malde, C.; Wang, R. Polyvinylidene fluoride membrane modification via oxidant-induced dopamine polymerization for sustainable direct-contact membrane distillation. J. Memb. Sci. 2018, 563, 31-42. [CrossRef]

57. El-Bourawi, M.S.; Ding, Z.; Ma, R.; Khayet, M. A framework for better understanding membrane distillation separation process. J. Memb. Sci. 2006, 285, 4-29. [CrossRef]

58. Wu, J.; Wang, L.; Dong, H.; Zhao, Y.; Jiang, L. Electrospun Porous Structure Fibrous Film with High Oil Adsorption Capacity. ACS Appl. Mater. Interfaces 2012, 4, 3207-3212. [CrossRef] [PubMed]

59. Li, X.; Wang, C.; Yang, Y.; Wang, X.; Zhu, M.; Hsiao, B.S. Dual-biomimetic superhydrophobic electrospun polystyrene nanofibrous membranes for membrane distillation. ACS Appl. Mater. Interfaces 2014, 6, 2423-2430. [CrossRef]

60. Li, X.; Deng, L.; Yu, X.; Wang, M.; Wang, X.; García-Payo, C.; Khayet, M. A novel profiled core-shell nanofibrous membrane for wastewater treatment by direct contact membrane distillation. J. Mater. Chem. A 2016, 4, 14453-14463. [CrossRef]

61. Wang, Z.; Wu, A.; Ciacchi, L.C.; Wei, G. Recent Advances in Nanoporous Membranes for Water Purification. Nanomaterials 2018, 8, 65. [CrossRef]

62. Dervin, S.; Dionysiou, D.D.; Pillai, S.C. 2D nanostructures for water purification: Graphene and beyond. Nanoscale 2016, 8 , 15115-15131. [CrossRef] 
63. Lee, A.; Elam, J.W.; Darling, S.B. Membrane materials for water purification: Design, development, and application. Environ. Sci. Water Res. Technol. 2016, 2, 17-42. [CrossRef]

64. Werber, J.R.; Osuji, C.O.; Elimelech, M. Materials for next-generation desalination and water purification membranes. Nat. Rev. Mater. 2016, 1, 1-16. [CrossRef]

65. Ahmed, F.E.; Lalia, B.S.; Hashaikeh, R. A review on electrospinning for membrane fabrication: Challenges and applications. Desalination 2014, 356, 15-30. [CrossRef]

66. Ullah, R.; Khraisheh, M.; Esteves, R.J.; McLeskey, J.T.; AlGhouti, M.; Gad-el-Hak, M.; Vahedi Tafreshi, H. Energy efficiency of direct contact membrane distillation. Desalination 2018, 433, 56-67. [CrossRef]

67. Achilli, A.; Cath, T.Y.; Marchand, E.A.; Childress, A.E. The forward osmosis membrane bioreactor: A low fouling alternative to MBR processes. Desalination 2009, 239, 10-21. [CrossRef]

68. McGinnis, R.L.; Elimelech, M. Energy requirements of ammonia-carbon dioxide forward osmosis desalination. Desalination 2007, 207. [CrossRef]

69. McCutcheon, J.R.; McGinnis, R.L.; Elimelech, M. A novel ammonia-carbon dioxide forward (direct) osmosis desalination process. Desalination 2005, 174. [CrossRef]

70. Martinetti, C.R.; Childress, A.E.; Cath, T.Y. High recovery of concentrated RO brines using forward osmosis and membrane distillation. J. Memb. Sci. 2009, 331. [CrossRef]

71. Petrotos, K.B.; Lazarides, H.N. Osmotic concentration of liquid foods. J. Food Eng. 2001, 49, 201-206. [CrossRef]

72. Sardari, K.; Fyfe, P.; Lincicome, D.; Wickramasinghe, S.R. Aluminum electrocoagulation followed by forward osmosis for treating hydraulic fracturing produced waters. Desalination 2018, 428, 172-181. [CrossRef]

73. Kiss, Z.L.; Kovács, I.; Veréb, G.; Hodúr, C.; László, Z. Treatment of model oily produced water by combined pre-ozonationmicrofiltration process. Desalin. Water Treat. 2016, 57, 23225-23231. [CrossRef]

74. Elimelech, M.; Phillip, W.A. The future of seawater desalination: Energy, technology, and the environment. Science 2011, 333, 712-717. [CrossRef]

75. Lee, K.P.; Arnot, T.C.; Mattia, D. A review of reverse osmosis membrane materials for desalination-Development to date and future potential. J. Memb. Sci. 2011, 370, 1-12. [CrossRef]

76. Chong, T.H.; Wong, F.S.; Fane, A.G. Implications of critical flux and cake enhanced osmotic pressure (CEOP) on colloidal fouling in reverse osmosis: Experimental observations. J. Memb. Sci. 2008, 314. [CrossRef]

77. Ba-Alawi, A.H.; Ifaei, P.; Li, Q.; Nam, K.J.; Djeddou, M.; Yoo, C.K. Process assessment of a full-scale wastewater treatment plant using reliability, resilience, and econo-socio-environmental analyses (R2ESE). Process Saf. Environ. Prot. 2020, 133, 259-274. [CrossRef]

78. Dudek, M.; Vik, E.A.; Aanesen, S.V.; Øye, G. Colloid chemistry and experimental techniques for understanding fundamental behaviour of produced water in oil and gas production. Adv. Colloid Interface Sci. 2020, 276, 102105. [CrossRef]

79. Turková, J.; Korytárová, J. Methods for Evaluation of WWTPs Environmental Impacts: A Review. IOP Conf. Ser. Earth Environ. Sci. 2019, 222. [CrossRef]

80. OSPAR. Background Document concerning Techniques for the Management of Produced Water from Offshore Installations; OSPAR Commission: Sintra, Portugal, 2013.

81. Awad, H.; Gar Alalm, M.; El-Etriby, H.K. Environmental and cost life cycle assessment of different alternatives for improvement of wastewater treatment plants in developing countries. Sci. Total Environ. 2019, 660, 57-68. [CrossRef]

82. Wenzlick, M.; Siefert, N. Techno-economic analysis of converting oil \& gas produced water into valuable resources. Desalination 2020, 481, 114381. [CrossRef]

83. Echchelh, A.; Hess, T.; Sakrabani, R. Reusing oil and gas produced water for irrigation of food crops in drylands. Agric. Water Manag. 2018, 206, 124-134. [CrossRef]

84. Arzate, S.; Pfister, S.; Oberschelp, C.; Sánchez-Pérez, J.A. Environmental impacts of an advanced oxidation process as tertiary treatment in a wastewater treatment plant. Sci. Total Environ. 2019, 694, 1-10. [CrossRef]

85. Jackson, L.M.; Myers, J.E. Design and Construction of Pilot Wetlands for Produced-Water Treatment. In Proceedings of the SPE Annual Technical Conference and Exhibition, Denver, Colorado, 5-8 October 2003; pp. 1-8.

86. Echchelh, A.; Hess, T.; Sakrabani, R.; de Paz, J.M.; Visconti, F. Assessing the environmental sustainability of irrigation with oil and gas produced water in drylands. Agric. Water Manag. 2019, 223, 105694. [CrossRef]

87. Environmental and Social Risk Briefing Oil \& Gas; Barclays Bank PLC: London, UK, 2015; pp. 1-26.

88. Ebrahimi, M.; Kovacs, Z.; Schneider, M.; Mund, P.; Bolduan, P.; Czermak, P. Multistage filtration process for efficient treatment of oil-field produced water using ceramic membranes. Desalin. Water Treat. 2012, 42, 17-23. [CrossRef]

89. Memon, S.; Kim, Y.D.; Soomro, S.; Soomro, M.I.; Kim, W.S. A new approach for freshwater production and energy recovery from an oil field. J. Water Process Eng. 2020, 34, 101145. [CrossRef]

90. Hoogmartens, R.; Van Passel, S.; Van Acker, K.; Dubois, M. Bridging the gap between LCA, LCC and CBA as sustainability assessment tools. Environ. Impact Assess. Rev. 2014, 48, 27-33. [CrossRef]

91. Risch, E.; Loubet, P.; Núñez, M.; Roux, P. How environmentally significant is water consumption during wastewater treatment?: Application of recent developments in LCA to WWT technologies used at 3 contrasted geographical locations. Water Res. 2014, 57, 20-30. [CrossRef] [PubMed] 
92. Molinos-Senante, M.; Hernández-Sancho, F.; Sala-Garrido, R. Economic feasibility study for new technological alternatives in wastewater treatment processes: A review. Water Sci. Technol. 2012, 65, 898-906. [CrossRef]

93. Al-Dosary, S.; Galal, M.M.; Abdel-Halim, H. Environmental Impact Assessment of Wastewater Treatment Plants. Int. J. Curr. Microbiol. Appl. Sci. 2015, 4, 953-964.

94. Dixon, A.; Simon, M.; Burkitt, T. Assessing the environmental impact of two options for small-scale wastewater treatment: Comparing a reedbed and an aerated biological filter using a life cycle approach. Ecol. Eng. 2003, 20, 297-308. [CrossRef]

95. McLaughlin, M.C.; Blotevogel, J.; Watson, R.A.; Schell, B.; Blewett, T.A.; Folkerts, E.J.; Goss, G.G.; Truong, L.; Tanguay, R.L.; Argueso, J.L.; et al. Mutagenicity assessment downstream of oil and gas produced water discharges intended for agricultural beneficial reuse. Sci. Total Environ. 2020, 715, 136944. [CrossRef]

96. Beylot, A.; Villeneuve, J. Accounting for the environmental impacts of sulfidic tailings storage in the Life Cycle Assessment of copper production: A case study. J. Clean. Prod. 2017, 153, 139-145. [CrossRef]

97. EPA Life Cycle Assessment: Principles and Practice. Vasa 2008, 88, 1-6. [CrossRef]

98. Planning and Statistics Authority. Infographic Indicators: Qatar's Sustainable Development Goals 2018; National Development Strategy: Doha, Qatar, 2018.

99. Hao, X.; Wang, X.; Liu, R.; Li, S.; van Loosdrecht, M.C.M.; Jiang, H. Environmental impacts of resource recovery from wastewater treatment plants. Water Res. 2019, 160, 268-277. [CrossRef]

100. Barjoveanu, G.; Comandaru, I.M.; Teodosiu, C. Life Cycle Assessment of Water and Wastewater Treatment Systems: An overview. Bull. Polytech. Inst. Iasi Chem. Chem. Eng. Sect. 2010, LVI, 73-86.

101. Adham, S.; Hussain, A.; Minier-Matar, J.; Janson, A.; Sharma, R. Membrane applications and opportunities for water management in the oil \& gas industry. Desalination 2018, 440, 2-17. [CrossRef]

102. Memon, F.A.; Zheng, Z.; Butler, D.; Shirley-Smith, C.; Lui, S.; Makropoulos, C.; Avery, L. Life cycle impact assessment of greywater recycling technologies for new developments. Environ. Monit. Assess. 2007, 129, 27-35. [CrossRef] [PubMed]

103. Beltrán, J.; Koo-Oshima, S. Water desalination for agricultural applications. In Proceedings of the FAO Expert Consultation on Water Desalination for Agricultural Applications, Rome, Italy, 26-27 April 2006.

104. Barron, O.; Ali, R.; Hodgson, G.; Smith, D.; Qureshi, E.; McFarlane, D.; Campos, E.; Zarzo, D. Feasibility assessment of desalination application in Australian traditional agriculture. Desalination 2015, 364, 33-45. [CrossRef]

105. Shannon, M.A.; Bohn, P.W.; Elimelech, M.; Georgiadis, J.G.; Marias, B.J.; Mayes, A.M. Science and technology for water purification in the coming decades. Nature 2008, 452, 301-310. [CrossRef] [PubMed]

106. Feitelson, E.; Rosenthal, G. Desalination, space and power: The ramifications of Israel's changing water geography. Geoforum 2012, 43, 272-284. [CrossRef]

107. March, H.; Saurí, D.; Rico-Amorós, A.M. The end of scarcity? Water desalination as the new cornucopia for Mediterranean Spain. J. Hydrol. 2014, 519, 2642-2651. [CrossRef]

108. Semiat, R. Energy issues in desalination processes. Environ. Sci. Technol. 2008, 42, 8193-8201. [CrossRef]

109. McCarty, P.L.; Bae, J.; Kim, J. Domestic wastewater treatment as a net energy producer-can this be achieved? Environ. Sci. Technol. 2011, 45, 7100-7106. [CrossRef]

110. Cao, X.; Huang, X.; Liang, P.; Xiao, K.; Zhou, Y.; Zhang, X.; Logan, B.E. A new method for water desalination using microbial desalination cells. Environ. Sci. Technol. 2009, 43, 7148-7152. [CrossRef]

111. Kokabian, B.; Gude, V.G. Sustainable photosynthetic biocathode in microbial desalination cells. Chem. Eng. J. 2015, 262, 958-965. [CrossRef]

112. Kim, Y.; Logan, B.E. Microbial desalination cells for energy production and desalination. Desalination 2013, 308, 122-130. [CrossRef]

113. Chen, X.; Xia, X.; Liang, P.; Cao, X.; Sun, H.; Huang, X. Stacked microbial desalination cells to enhance water desalination efficiency. Environ. Sci. Technol. 2011, 45, 2465-2470. [CrossRef] [PubMed]

114. Ping, Q.; He, Z. Improving the flexibility of microbial desalination cells through spatially decoupling anode and cathode. Bioresour. Technol. 2013, 144, 304-310. [CrossRef]

115. Forrestal, C.; Xu, P.; Ren, Z. Sustainable desalination using a microbial capacitive desalination cell. Energy Environ. Sci. 2012, 5, 7161-7167. [CrossRef]

116. Kim, Y.; Logan, B.E. Series assembly of microbial desalination cells containing stacked electrodialysis cells for partial or complete seawater desalination. Environ. Sci. Technol. 2011, 45, 5840-5845. [CrossRef]

117. Liu, G.; Luo, H.; Tang, Y.; Chen, S.; Zhang, R.; Hou, Y. Tetramethylammonium hydroxide production using the microbial electrolysis desalination and chemical-production cell. Chem. Eng. J. 2014, 258, 157-162. [CrossRef]

118. Zhang, Y.; Angelidaki, I. A new method for in situ nitrate removal from groundwater using submerged microbial desalinationdenitrification cell (SMDDC). Water Res. 2013, 47, 1827-1836. [CrossRef]

119. Zuo, K.; Cai, J.; Liang, S.; Wu, S.; Zhang, C.; Liang, P.; Huang, X. A ten liter stacked microbial desalination cell packed with mixed ion-exchange resins for secondary effluent desalination. Environ. Sci. Technol. 2014, 48, 9917-9924. [CrossRef]

120. Cath, T.Y.; Childress, A.E.; Elimelech, M. Forward osmosis: Principles, applications, and recent developments. J. Memb. Sci. 2006, 281, 70-87. [CrossRef]

121. Zhao, S.; Zou, L.; Tang, C.Y.; Mulcahy, D. Recent developments in forward osmosis: Opportunities and challenges. J. Memb. Sci. 2012, 396, 1-21. [CrossRef] 
122. Lutchmiah, K.; Verliefde, A.R.D.; Roest, K.; Rietveld, L.C.; Cornelissen, E.R. Forward osmosis for application in wastewater treatment: A review. Water Res. 2014, 58, 179-197. [CrossRef]

123. Liu, Z.; Bai, H.; Lee, J.; Sun, D.D. A low-energy forward osmosis process to produce drinking water. Energy Environ. Sci. 2011, 4, 2582-2585. [CrossRef]

124. Qin, M.; He, Z. Self-Supplied Ammonium Bicarbonate Draw Solute for Achieving Wastewater Treatment and Recovery in a Microbial Electrolysis Cell-Forward Osmosis-Coupled System. Environ. Sci. Technol. Lett. 2014, 1. [CrossRef]

125. Lu, Y.; Qin, M.; Yuan, H.; Abu-Reesh, I.M.; He, Z. When bioelectrochemical systems meet forward osmosis: Accomplishing wastewater treatment and reuse through synergy. Water 2015, 7, 38-50. [CrossRef]

126. Zhang, B.; He, Z. Improving water desalination by hydraulically coupling an osmotic microbial fuel cell with a microbial desalination cell. J. Memb. Sci. 2013, 441, 18-24. [CrossRef]

127. Konieczny, K.H.; Wszelaka-Rylik, M.; Macherzyński, B. Membrane processes innovation in environmental protection: Review. Arch. Environ. Prot. 2019, 45, 20-29. [CrossRef]

128. Ping, Q.; Zhang, C.; Chen, X.; Zhang, B.; Huang, Z.; He, Z. Mathematical model of dynamic behavior of microbial desalination cells for simultaneous wastewater treatment and water desalination. Environ. Sci. Technol. 2014, 48, 13010-13019. [CrossRef]

129. Ping, Q.; He, Z. Effects of inter-membrane distance and hydraulic retention time on the desalination performance of microbial desalination cells. Desalin. Water Treat. 2014, 52, 1324-1331. [CrossRef]

130. Ping, Q.; Cohen, B.; Dosoretz, C.; He, Z. Long-term investigation of fouling of cation and anion exchange membranes in microbial desalination cells. Desalination 2013, 325, 48-55. [CrossRef]

131. Yuan, L.; Yang, X.; Liang, P.; Wang, L.; Huang, Z.H.; Wei, J.; Huang, X. Capacitive deionization coupled with microbial fuel cells to desalinate low-concentration salt water. Bioresour. Technol. 2012, 110, 735-738. [CrossRef]

132. Morel, A.; Zuo, K.; Xia, X.; Wei, J.; Luo, X.; Liang, P.; Huang, X. Microbial desalination cells packed with ion-exchange resin to enhance water desalination rate. Bioresour. Technol. 2012, 118, 243-248. [CrossRef]

133. Lin, H.; Peng, W.; Zhang, M.; Chen, J.; Hong, H.; Zhang, Y. A review on anaerobic membrane bioreactors: Applications, membrane fouling and future perspectives. Desalination 2013, 314, 169-188. [CrossRef]

134. Kim, S.L.; Paul Chen, J.; Ting, Y.P. Study on feed pretreatment for membrane filtration of secondary effluent. Sep. Purif. Technol. 2002, 29, 171-179. [CrossRef]

135. Alzahrani, S.; Mohammad, A.W. Challenges and trends in membrane technology implementation for produced water treatment: A review. J. Water Process Eng. 2014, 4, 107-133. [CrossRef]

136. Al-Ghouti, M.A.; Al-Kaabi, M.A.; Ashfaq, M.Y.; Da'na, D.A. Produced water characteristics, treatment and reuse: A review. J. Water Process Eng. 2019, 28, 222-239. [CrossRef]

137. Ezugbe, E.O.; Rathilal, S. Membrane technologies in wastewater treatment: A review. Membranes 2020, 10, 89. [CrossRef] [PubMed] 